\title{
Eksperimentasi Model Pembelajaran Problem Based Learning dalam Pembelajaran Nahwu di Kelas X SMA
}

\author{
Muhammad Sya'dullah Fauzi ${ }^{1}$ \\ Universitas Islam Negeri Sunan Kalijaga Yogyakarta, Indonesia ${ }^{1}$ \\ Email: fauzisadullah97@gmail.com ${ }^{1}$
}

\begin{abstract}
:
Purpose- This article aims to explain the results of research on how to use problem based learning (PBL) learning models in Nahwu learning; and to find out the effect of the problem based learning (PBL) learning model on Nahwu's results at Wahid Hasyim Sleman Science High School, especially in class X.

Design/Methodology/Approach- This type of research is Experimental Research with comparative data between the experimental class and the control class. While the sample in this study was class X Mipa 1 as the experimental class and class X IPS as the control class.

Findings - From the results of this study it was found that the average value of the experimental class students before the PBL learning model was applied was 74. While the average value of the control class students before being given treatment (conventional learning model) was 72 . The average value of the control class students was 72. the experiment after the PBL learning model was applied was 85, and the average control class after being treated was 74.i From the results of the $T$ test analysis, a significance value of 0.000 was obtained. That is, the PBL learning model has an effect on improving student Nahwu learning outcomes. And from the results of the $\mathrm{N}$-Gain the experimental class is 11 while the control class is 2 . This shows that the class given the problem based learning model is on average larger than the class that is applied to the conventional learning model. The difference is significant. That is, the $P B L$ learning model has an effect on improving the learning outcomes of Nahwu students of class X SMA Sains Wahid Hasyim Sleman.
\end{abstract}

Research Limitation/Implications- The results of this study contributes to the innovation in Nahwu learning through the implementation of Problem-Based Learning. However, this research does not cover wider scope than the implenentation and it does not focus on the development of Problem-Based Learning model in Nahwu learning.

Keyword: Learning Model, Problem-Based Learning, Nahwu Learning Outcomes

\begin{abstract}
Abstrak
Purpose- artikel ini bertujuan untuk memaparkan hasil penelitian tentang bagaimana penggunaan model pembelajaran problem based learning $(P B L)$, dalam pembelajaran Nahwu; serta untuk mengatahui pengaruh penggunaan model pembelajaran problem based learning (PBL) terhadap hasil belajar siswa pada pelajaran Nahwu di SMA Sains Wahid Hasyim Sleman khususnya di kelas X.

Design/Methodology/Approach- Jenis penelitian ini merupakan Eksperimental Research di mana datanya bersifat komparasi (perbandingan) antara kelas eksperimen dan kelas kontrol. Sedangkan Sampel dalam penelitian ini adalah kelas X Mipa 1 sebagai kelas eksperimen dan kelas X IPS sebagai kelas kontrol.
\end{abstract}


Findings - Dari hasil penelitian ini ditemukan bahwa besarnya nilai rata-rata siswa kelas eksperimen sebelum diterapkan model pembelajaran $P B L$ yaitu sebesar 74 . Sedangkan nilai rata-rata siswa kelas kontrol sebelum diberikan perlakuan (model pembelajaran konvensional) yaitu sebesar 72. Adapun nilai rata-rata siswa kelas eksperimen setelah diterapkan model pembelajaran $P B L$ yaitu sebesar 85 , dan ratarata kelas kontrol setelah diberi perlakuan sebesar 74. Dari hasil analisis uji T diperoleh nilai signifikansi sebesar 0,000. Artinya, model pembelajaran $P B L$ berpengaruh dalam meningkatkan hasil belajar Nahwu siswa. Dan dari hasil N-Gain kelas eksperimen sebesar 11 sedangkan kelas kontrol sebesar 2. Ini menunjukkan kelas yang diberikan model pembelajaran problem based learning rata-ratanya lebih besar dari kelas yang diterapkan model pembelajaran konvensional. Adapun perbedaannya signifikan. Artinya, model pembelajaran $P B L$ berpengaruh dalam meningkatkan hasil belajar Nahwu siswa kelas X SMA Sains Wahid Hasyim Sleman.

Research Limitation/Implications- Hasil dari penelitian ini memberikan kontribusi terhadap inovasi dalam pembelajaran Nahwu. Yaitu dengan menerapkan Problem Based Learning dalam pembelajaran Nahwu. Hanya saja, penelitian ini belum mencakup skala yang lebih luas dan kurang memfokuskan pada pengembangan model Problem Based Learning dalam pembelajaran Nahwu.

Kata kunci: Model pembelajaran, Problem Based Learning, Hasil belajar Nahwu.

\section{PENDAHULUAN}

Di antara bahasa yang paling banyak digunakan oleh penduduk dunia adalah bahasa arab. Hal tersebut karena bahasa Arab adalah bahasa yang menjadi bahasa utama dalam Al-Qur'an dan Hadits yang mana keduanya menjadi pedoman bagi umat Islam di dunia. Untuk itu, bahasa Arab menjadi penng untuk dipelajari karena ia menjadi salah satu langkah awal untuk mempelajari khazanah keilmuan Islam. Bukan itu saja, bahasa Arab juga menjadi bahasa yang digunakan dalam berbagai ibadah bagi umat Islam. Sehingga, setiap Muslim sangat perlu untuk mempalajari dan menguasainya.

Dalam kaitannya dengan keilmuan, Bahasa Arab bukanlah disiplin ilmu yang berdiri sendiri. Ada empat keterampilan (maharah) dalam berbahasa Arab yang harus dikuasai pembelajarnya, yaitu keterampilan menyimak, berbicara, membaca, dan kemahiran menulis. ${ }^{1}$ Dan untuk menguasai keempat keterampilan tersebut diperlukan cabang ilmu yang biasa disebut dengan ilmu Nahwu dan Sharaf. Namun yang lebih difokuskan dalam hal ini adalah ilmu Nahwu, karena dengan ilmu Nahwu, seseorang aka lebih mudah dalam mempelajari aspek-aspek

\footnotetext{
${ }^{1}$ Acep Hermawan, Metodologi Pembelajaran Bahasa Arab (Jakarta: PT. Rosda Karya, 2011)
} hlm 129. 
lain dalam bahasa arab. $^{2}$ Dalam ungkapan yang paling terkenal, diungkapkan bahwa ilmu Nahwu adalah ilmu yang melihat perbedaan terakhir pada setiap kata dalam sebuah kalimat karena adanya amil (pengaruh) yang mendahuluinya. ${ }^{3}$

Sebagian ulama menyatakan bahwa hukum mempelajari ilmu Nahwu untuk mendalami al-Qur'ān dan Hadits yang notabenenya berbahasa Arab adalah farḍu 'ain. Hal ini Karena seseorang tidak mungkin mampu menggali hukum dan menetapkan suatu hukum (istimbat hukum) tanpa menguasai ilmu Nahwu Saraf. ${ }^{4}$ Jika pembelajar bahasa Arab mengabaikan ilmu Nahwu, maka susunan kata dan kalimat yang ia produksi (baik lisan maupun tulisan) akan menjadi tidak beraturan. Dengan demikian, dalam pembelajaran bahasa Arab, ilmu Nahwu menjadi kebutuhan yang penting untuk dipelajari.

Beberapa lembaga pendidikan Islam terutama yang berbasis pesantren, ilmu Nahwu adalah salah satu mata pelajaran yang popular dipelajari. Hal ini mengingat kurikulum pesantren sangat erat kaitannya dengan literatur-literatur berbahasa Arab. Sehingga dalam rangka memenuhi target kurikulum, peserta didik harus dibekali dengan ilmu Nahwu sebagai ilmu alat mempelajari bahasa Arab.

Namun permasalahannya, banyak dari siswa yang merasa kesulitan dalam proses belajar. Kesulitan belajar merupakan suatu kondisi di mana siswa tidak mampu untuk melakukan porses belajar dengan baik. ${ }^{5}$ Hal ini disebabkan karena dua faktor, Yaitu faktor intern dan ekstern. Faktor intern misalnya karena siswa menderita suatu penyakit atau mengalami kecacatan. Sedangkan Faktor ekstern seperti kondisi ekonomi keluarga yang cenderung kurang, kondisi keluarga yang kurang harmonis, strategi mengajar yang cenderung membuat siswa bosan, dan fasilitas belajar yang kurang lengkap. ${ }^{6}$

Di antara faktor pembelajar mengalami kesulitan dalam pembelajaran Nahwu adalah persepsi tentang ilmu Nahwu itu sendiri. Banyak dari pembelajar

${ }^{2}$ Ali Akrom Fahmi, Ilmu Nahwu Dan Sharaf 2 (Tata Bahasa) Praktis Dan Aplikatif (Jakarta: Raja Grafindo Persada, 1995) hlm, xi.

3 Afif Kholisun Nashoih and M. Faridl Darmawan, "Pengembangan Bahan Ajar Nahwu Berbasis Kontrastif Untuk Mengatasi Interferensi Bahasa Indonesia Terhadap Bahasa Arab," Arabiyatuna: Jurnal Bahasa Arab 3, no. 2 (2019): 335.

${ }^{4}$ Ma'rifatun, "Strategi Pembelajaran Nahwu Saraf Di MA Pondok Pesantren," Jurnal Al-Ghazali 2, no. 2 (2019): 103-116, https://ejournal.stainupwr.ac.id/.

5 Dalyono, Psikologi Pendidikan (Jakarta: Rineka Cipta) hlm. 229.

${ }^{6}$ Ana Wahyuning Sari, "Analisis Kesulitan Pembelajaran Nahwu Pada Siswa Kelas Viii Mts Al Irsyad Gajah Demak Tahun Ajaran 2015/2016," Lisanul' Arab: Journal of Arabic Learning and Teaching 6, no. 1 (2017): 16-17. 
ketika mendengar kata Nahwu mereka menganggapnya sebagai sesuatu yang menakutkan. Selain itu, kesulitan belajar Nahwu juga disebabkan karena penggunaan metode dan model pembelajaran yang kurang menarik dan kurang sesuai. ${ }^{7}$

Berdasarkan hasil wawancara dengan guru Nahwu kelas X Bapak Ilfan Fauzi, S. Pd. Didapati bahwa hasil nilai ulangan harian dan ulangan akhir semester (UAS) pada mata pelajaran Nahwu kelas X di SMA Sains Wahid Hasyim Sleman pada tahun ajaran 2018/2019, sebanyak 60\% siswa tidak mencapai Kriteria Ketuntasan Minimal (KKM) serta kurangnya minat partisipasi aktif siswa dalam proses pembelajaran Nahwu. ${ }^{8}$

Kondisi tersebut membuat guru untuk dapat memanfaatkan model pembelajaran Nahwu yang lebih variatif dan tepat sesuai materi Nahwu yang harus difokuskan lebih dulu untuk diajarkan kepada siswa, sehingga dapat mempermudah siswa mempelajari ilmu Nahwu. menurut peneliti, di antara model pembelajaran yang layak untuk diterapkan dalam pembelajaran ilmu Nahwu adalah model Problem Based Learning(PBL).

Problem Based Learning (PBL) adalah satu model pembelajaran yang disusun untuk membiasakan siswa dalam memecahkan suatu permasalahan. Jadi, proses PBL harus dilaksanakan secara kooperatif dan kolaboratif di mana siswa belajar dalam suatu kelompok kecil yang difasilitasi seperti halnya ketika siswa belajar secara mandiri. ${ }^{9}$ Model pembelajaran ini dianggap peneliti dapat meningkatkan minat dan partisipasi aktif siswa dalam pembelajaran Nahwu. Dengan demikian, PBL juga dapat memberikan pengaruh terhadap hasil belajar siswa dalam mata pelajaran Nahwu menjadi lebih baik.

Berdasarkan hasil kajian yang dilakukan Puji Rahayu Ningsih, dkk, dalam artikelnya yang berjudul "Penerapan Problem Based Learning untuk Meningkatkan Kemampuan Berpikir Kritis dan Hasil Belajar Siswa Kelas III" menunjukkan bahwa terjadi peningkatan pada aspek 'kemampuan berpikir kritis' yang mana pada siklus pertama sebesar 63,49\% menjadi $76,98 \%$ pada siklus kedua dan meningkat lagi menjadi $84,12 \%$ pada sikus ketiga. Sedangkan 'Hasil

7 Aisyam Mardliyyah, "Implementasi Metode Qiyasi Dalam Pembelajaran Nahwu Kelas XI MA Ibnu Qoyyim Putra Yogyakarta," at-Tarbawi 4, no. 2 (2019).

8 Ilfan Fauzi, Guru Nahwu SMA Sains Wahid Hasyim Sleman "Wawancara tidak terstruktur"

9 Alimul Muniroh, Academic Engagement; Penerapan Model Problem Based Learning Di Madrasah (Yogyakarta: LKIS, 2015) hlm.37. 
belajar sikap' meningkat dari 47,62\% menjadi $85,71 \%$ dan pada siklus III meningkat menjadi 95,23\%. Adapun 'hasil belajar' meningkat dari 47,62\%, menjadi 76, 19\%, dan pada siklus III menjadi 80,95\%. Pada aspek 'Hasil belajar keterampilan' juga mengalami peningkatan yang cukup signifikan pada siklus II. Yaitu dari 52,38\%, menjadi 95,21\%, dan siklus III sedikit mengalami penurunan menjadi $76,19 \% .^{10}$ Persamaan dengan penelitian ini terletak pada model pembelajaran yang digunakan yaitu Problem Based Learning .

Hal senada juga dilakukan oleh Nina, Dkk. dalam jurnalnya "Pengaruh Model Pembelajaran Berbasis Masalah Terhadap Hasil Belajar Peserta Didik Pada Materi Peristiwa Alam". Penelitian ini menyimpulkan bahwa pembelajaran IPA yang menggunakan model PBL dan model pembelajaran konvesional (tradisional) sama-sama dapat meningkatkan hasil belajar siswa khususnya pada materi peristiwa alam. Namun, pembelajaran PBL lebih unggul dibanding model pembelajaran tradisional. Terlihat dari hasil statistik uji rata-rata perhitungan ngain kelas eksperimen yang memperoleh nilai 0,70 sedikit lebih besar dibanding perhitungan rata-rata uji n-gain kelas kontrol yang memperoleh hasil 0,60.11

Berdasarkan berbagai kajian terdahulu yang telah disebutkan di atas, model problem based learning dapat berpengaruh terhadap peningkatan hasil belajar siswa. Untuk itu, peneliti tertarik melakukan penelitian berbasis eksperimen tentang pengaruh model Problem Based Learning terhadap hasil belajar Nahwu siswa SMA Sains Wahid Hasyim Sleman kelas X. Tujuannya untuk mengetahui bagaimana implementasi model pembelajaran problem based learning (PBL), serta untuk mengatahui bagaimana pengaruh penerapan model pembelajaran Problem Based Learning (PBL) terhadap hasil belajar Nahwu di SMA Sains Wahid Hasyim Sleman khususnya di kelas X.

\section{METODE PENELITIAN}

Penelitian ini dilakukan di SMA Sains Wahid Hasyim Sleman, khusunya di kelas X pada tahun ajaran 2019/2020 semester genap dan dilaksanakan pada

10 Puji Rahayu Ningsih, Arif Hidayat, and Sentot Kusairi, "Penerapan Problem Based Learning Untuk Meningkatkan Kemampuan Berpikir Kritis Dan Hasil Belajar Siswa Kelas III," Jurnal Pendidikan: Teori , Penelitian dan Pengembangan 3, no. 12 (2018): 1587-1593, http://journal.um.ac.id/index.php/jptpp/.

11 Nina Nurliani, Herman Subarjah, and Atep Sujana, "Pengaruh Model Pembelajaran Berbasis Masalah Terhadap Hasil Belajar Peserta Didik Pada Materi Peristiwa Alam," Jurnal Pena Ilmiah 1, no. 1 (2016): 981-990. 
bulan Januari 2020. Penelitian ini menggunakan pendekatan kuantitatif, karena penelitian ini menekankan pada pengumpulan data kuantitatif dan penggunaan analisis statisitik dalam pemaparan dan analisis data, serta pengujian hipotesis dan pengambilan kesimpulannya. Metode penelitian yang digunakan adalah metode Quasi Experimental Design.

Desain dari Penelitian ini adalah non equivalent control group design. Ada dua kelompok dalam desain penelitian ini, yaitu kelas kontrol dan kelas eksperimen. Kelas eksperimen merupakan kelas yang mendapatkan perlakuan eksperimen, dalam hal ini berupa penerapan model problem based learning. Adapun kelas kontrol merupakan kelas yang tidak mendapat perlakuan. Kelas kontrol juga berpera sebagai kelas pengendali. Pada desain ini baik kelas eksperimen maupun kelas kontrol sama-sama tidak dipilih secara random.

Peneliti menggunakan populasi seluruh siswa kelas X SMA Sains Wahid Hasyim tahun ajaran 2019/2020 yang berjumlah 150 siswa. Di mana dari total kelas X tersebut dibagi dalam 5 kelompok belajar. Yaitu 4 kelompok peminatan MIPA dan 1 kelompok peminatan IPS. Namun karena keterbatasan waktu untuk memberikan tindakan kepada semua populasi, maka peneliti menggunakan teknik simple random sampling. Yaitu peneliti menggunaka 2 kelas sebagai sampel penilitan, satu kelas sebagai kelas eksperimen dan satu kelas sebagai kelas kontrol.

Peneliti menggunakan kelas X MIPA 1 sebagai kelas eksperimen dengan menerapkan model pembelajaran problem based learning pada mata pelajaran Nahwu, dan kelas X IPS sebagai kelas kontrol dengan menggunakan model pembelajaran konvensional pada mata pelajaran Nahwu. Kedua kelas tersebut sama-sama berjumlah 30 siswa.

Adapun pengumpulan datanya menggunakan teknik wawancara, dokumentasi, dan tes. Tes yang digunakan meliputi pretest dan posttest yang mana butir-butir soalnya sebelumnya sudah dilakukan uji validasi dan reliabilitas sebagai uji prasyarat instrument tes.

Sedangkan prosedur analisis data diawali dengan uji normalitas terlebih dahulu. Hal ini perlu bertujuan untuk mengetahui apakah sampel penelitian berasal dari populasi yang berdistribusi normal atau tidak. Pada penelitian ini, untuk menguji normalitas data menggunakan uji normalitas "Kolmogrov-Smirnov" dengan bantuan software SPSS 20 untuk perhitungan datanya. 
Selanjutnya adalah uji homogenitas. Uji homogenitas dilakukan untuk mengetahui apakah kedua kelompok data sampel berasal dari populasi yang memiliki varian yang sama atau tidak. Peneliti menggunakan rumusan Anova untuk uji homogenitas ini. ${ }^{12}$

Setelah data dihasilkan oleh peneliti, maka langkah selanjutnya yaitu data diuji T. dalam menganalisis data peneliti menggunakan analisis kuantitatif menggunakan model statistik. Untuk mengetahui apakah model pembelajaran PBL berpengaruh terhadap hasil belajar Nahwu, maka peneliti menggunakan uji paired sample t test pada SPSS.

\section{Hasil Penelitian dan Pembahasan}

\section{Konsep Model Pembelajaran Problem Based Learning}

Perkembagan di abad 21 ini membuat pendidikan terkait dengan permasalahan baru yang ada di dunia nyata. Sehingga pendidikan tidak cukup hanya untuk menyiapkan masa depan, lebih dari itu, pendidikan harus bisa menciptakan masa depan. Pendidikan harus dapat mengembangkan individu menjadi lebih kritis dan kreatif serta memilik keterampilan berpikir tingkat tinggi. ${ }^{13}$ Untuk itu, model Problem Based Learning hadir untuk merespon perkembangan pendidikan yang amat pesat.

PBL adalah model pembelajaran yang mengumpulkan dan mengintegrasikan pengetahuan baru dengan suatu masalah sebagai langkah awal dalam proses pembelajaran. ${ }^{14}$ Arends menyatakan bahwa Problem Based Learning adalah sebuah model pembelajaran yang berorinteasi pada pemecahan suatu masalah. PBL mencoba menghadirkan berbagai situasi masalah yang nyata dan bermakna kepada siswa, yang dapat digunakan untuk

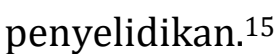

Boud dan Feletti (1997) menyatakan bahwa PBL merupakan inovasi yang paling utama dalam pendidikan. Margeston (1994) berpendapat bahwa kurikulum 2017).

12 Imam Machalli, Metode Penelitian Kuantitatif (Yogyakarta: Pustaka an-Nur liq an-Nur,

13 Rusman, Model-Model Pembelajaran: Mengembangkan Profesionalisme Guru (Rajawali Pers/PT Raja Grafindo Persada, 2011) Hlm. 230.

14 Nelfiyanti and Didi Sunardi, "PENERAPAN METODE PROBLEM BASED LEARNING DALAM PELAJARAN AL - ISLAM II DI FAKULTAS TEKNIK UNIVERSITAS MUHAMMADIYAH JAKARTA," Spektrum Industri 15, no. 1 (2017): 1-119.

${ }^{15}$ Muniroh, Academic Engagement; Penerapan Model Problem Based Learning Di Madrasah. HIm. 37 
PBL dapat membantu siswa untuk meningkatkan dan mengembangkan keterampilan belajar aktif dalam pola pikir yang reflektif, kritis, dan dinamis. Kurikulum berbasis PBL berfungsi untuk membantu keberhasilan memecahkan masalah, komunikasi, kerja sama dan keterampilan relasional dengan lebih baik dibandingkan dengan pendekatan yang lain. ${ }^{16}$

John Dewey membangun dasar filosofis PBL lewat penelitiannya yang berjudul Democracy and Education pada tahun 1916. ${ }^{17}$ Dewey mengemukakan pandangan yang luar biasa tentang pendidikan. Ia mengatakan bahwa sekolah harus memiliki kemampuan untuk mencerminkan masyarakat yang lebih luas dan kelas sebagai fasilitas penelitian (laboratorium) untuk menyelesaikan berbagai permasalahan yang muncul di kehidupan nyata. Sebagai konsekuensinya, Dewey menyarankan para pendidik untuk mendorong siswa mereka agar membiasakan diri untuk terlibat dalam berbagai kegiatan yang berhubungan dengan pemecahan masalah. Adapaun program pembelajaran yang ada di sekolah harus kontekstual dan memiliki manfaat yang nyata. Hal ini karena siswa perlu membiasakan diri untuk memecahkan masalah tersebut dalam kerja kelompok dalam suatu kelompok kecil sebagai pembiasaan ketika nanti siswa sudah terjun d dunia sosial yang sebenarnya. ${ }^{18}$

Penelitian lain juga dilakukan oleh Jean Piaget dan Lev Vygotsky. Keduanya merupakan ahli psikologi Eropa yang terkenal dengan tokoh konstruktivisme. Atas dasar konsep itulah Problem Based Learning dilaksanakan. Dalam penelitiannya, Piaget mempelajari cara berpikir pada anak dan proses-proses yang berkaitan dengan perkembangan kecerdasan anak. Ia menjelaskan bahwa sejak lahir, anakanak sudah memiliki potensi rasa ingin tahu dan terus berusaha memahami lingkungan yang ada di sekitar mereka. Rasa ingin tahu tersebut yang menjadi motivasi anak untuk aktif melakukan konstruksi gambaran-gambaran dalam benak mereka tentang lingkungan sekitarnya. 19

Adapun langkah-langkah model pembelajaran Problem Based Learning (PBL) adalah: a) guru mengorientasikan siswa pada suatu masalah, b) guru membentuk kelompok kecil beranggotakan 5-6 siswa secara heterogen setiap

16 Rusman, Model-Model Pembelajaran: Mengembangkan Profesionalisme Guru. Hlm. 230.

${ }^{17}$ Arends, Learning to Teach, 6th ed. (New York: McGrawHill, 2008).

18 Ibid.

${ }^{19}$ Ibid. 
kelompoknya; c) guru membagikan Lembar Kerja Siswa (LKS) pada setiap kelompoknya; d) siswa mencari informasi yang sesuai dengan permasalahan, kemudian siswa bersama kelompoknya melakukan diskusi dan percobaan untuk memecahka permasalahan; e) guru membantu siswa untuk menyajikan hasil eksperimen; f ) guru meminta siswa untuk mempresentasikan hasil penyelesaian masalahnya; g) guru memberikan evaluasi terhadap hasil pemecahan masalah yang dilakukan oleh siswa. ${ }^{20}$

Secara sederhana, Problem Based Learning (PBL) memiliki karakteristik tersendiri, yaitu: 1) Pembelajaran berpusat pada siswa, 2) Pembelajaran terjadi pada kelompok kecil siswa, 3) Guru bertindak sebagai fasilitator, 4) masalah menjadi fokus dan stimulus utama dalam proses pembelajaran, 5) masalah berfungsi sebagai jalan untuk mengembangkan kemampuan pemecahan masalah secara klinis, dan 6) informasi dan pengetahuan baru diperoleh melalui pembelajaran yang mengarahkan diri. ${ }^{21}$

Namun lebih jauh lagi Problem Based Learning juga memiliki esensi seperti yang telah dipaparkan oleh Barrows sebagai berikut: 1) Siswa harus memiliki rasa tanggung jawab terhadap belajarnya sendiri. 2) Permasalahan yang diangkat dalam PBL harus bersifat ill-structured (atau belum terstruktur dan belum terselesaikan dengan baik), 3) proses belajar harus terintegrasi dengan berbagai disiplin ilmu dan pengetahuan lain, 4) proses pembelajaran dilakukan secara kolaboratif dan kooperatif (untuk sharing dan diskusi tentang suatu informasi dan ide) untuk memecahkan suatu permasalahan. 5) sesuatu yang telah siswa pelajari dalam belajar mandiri harus diterapkan dalam pemecahan permasalahan melalui reanalisis dan resolution. 6) Analisis akhir tentang sesuatu yang telah dipelajari dari pemecahan masalah dan konsep atau teori apa yang telah dipelajari melalui diskusi merupakan suatu hal yang penting. 7) Self dan peer assessment harus dilakukan setiap pemecahan suatu masalah, atau setiap unit program PBL. 8) PBL harus dilaksanakan secara bermakna dalam kehidupan sehari-hari. 9) pelaksaan ujian harus dapat mengukur progres siswa dalam mencapai tujuan model

20 R. Tyas, "Kesulitan Penerapan Problem Based Learning Dalam Pembelajaran Matematika," Tecnoscienza 2, no. 1 (2017): 43-52.

${ }^{21}$ M. Taufiq Amir, Inovasi Pendidikan Melalui Problem Based Learning, Bagaimana Pendidik Memberdayakan Pemelajar Di Era Pengetahuan (Jakarta: Kencana, 2009). 
pembelajaran PBL. 10) secara pedagogis, PBL harus didasarkan pada kurikulum, dan bukan menjadi bagian dari kurikulum. ${ }^{22}$

Lebih lanjut titik poin dalam karakteristik PBL ini adalah menempatkan permasalahan menjadi starting point dalam belajar, permasalahan dijadikan kebutuhan dalam perspektif ganda (multiple perspective), menjadikan sistem belajar sebagai sistem yang kolaboratif, komunikatif, dan kooperatif, serta menjadikan proses belajar sebagai bentuk pengarahan diri menjadi hal yang utama. $^{23}$

Perumusan masalah dalam acuan proses pembelajaran harus memperhatikan kondisi siswa dan lingkungan belajar agar penyajian materi tersusun dengan baik dan menarik. Di antara hal-hal yang perlu diperhatikan sebelum merumuskan masalah dalam PBL yaitu 1) kinerja siswa yang dianggap tidak sesuai atau kurang sesuai, 2) sitausi dan kondisi yang menuntut adaya perhatian dan peningkatan yang lebih, 3) selalu mencari strategi dan skema yang lebih baik atau menciptakan hal baru yang meranah pada konteks materi pembelajaran, 4) masalah yang digunakan merupakan fenomena yang masih menjadi misteri atau belum dapat diselesaikan, 5) adanya kesenjangan antara informasi dan pengetahuan, 6) masalah mengambil keputusan. ${ }^{24}$

Adapun dalam penyajian alur pembelajaran PBL dimulai dari studi kasus pembelajaran meliputi penyajian suatu masalah, menggerakkan inquiry, dan langkah-langkah PBL seperti analisis inisial, mengangkat isu-isu belajar, letarasi kemandirian dan kolaborasi dalam pemecahan masalah. Alur penyajian dapat dilihat pada gambar dibawah ini:

22 J.R Savery, "Overview Of Problem-Based Learning: Devinition and Distinction Interdisciplinary," Journal Problem-based Learning 1, no. 1 (2006): 9-20, https://doi.org/10.7771/15415015.1002.

${ }^{23}$ Rusman, Model-Model Pembelajaran: Mengembangkan Profesionalisme Guru. HIm. 232.

24 Amir, Inovasi Pendidikan Melalui Problem Based Learning, Bagaimana Pendidik Memberdayakan Pemelajar Di Era Pengetahuan. HIm. 18-19. 


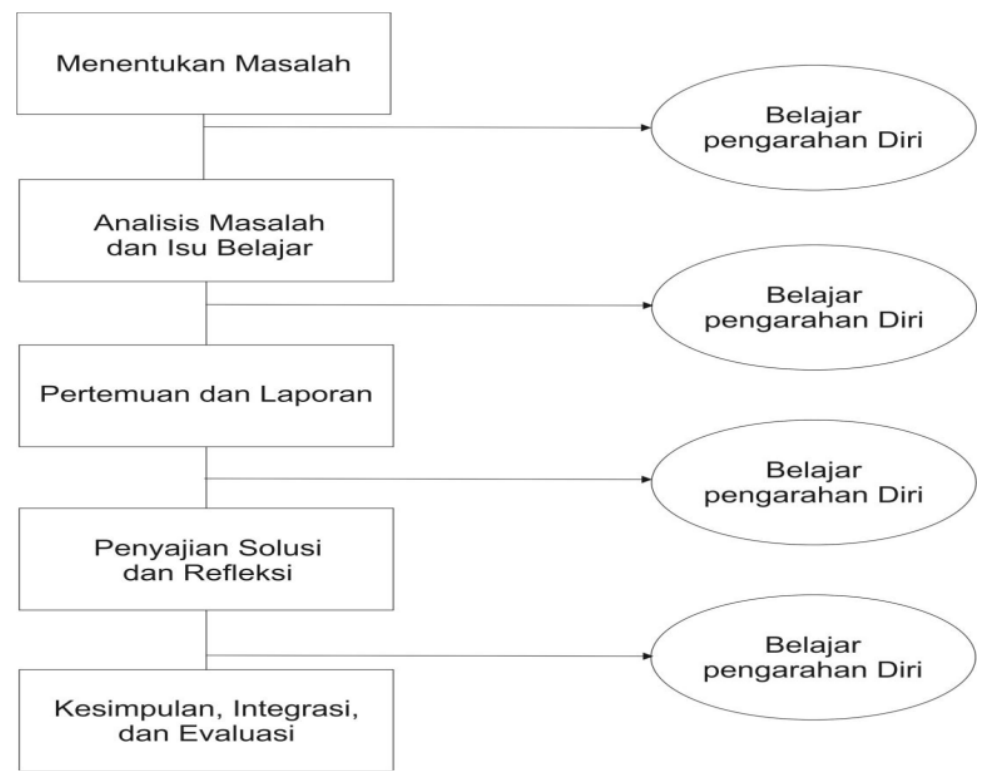

Gambar. 1 Keberagaman Pendekatan PBL

Gambar di atas menunjukkan bahwa proses starting point PBL dimulai dari penentuan masalah yang akan dibahas sebagai basis tujuan yang nantinya akan dibuat untuk pemahaman rekontruktif siswa dalam mempelajari materi yang telah ditetapkan. Kemudian melakukan proses analisis dengan menggunakan pemahaman kognitif siswa dalam memecahkan masalah yang telah disajikan, menemukan pola pemiiran yang kolaboratif dan integratif serta menemukan solusi baru sebagai gol praktik pembelajaran dari masalah yang sudah ditentukan. Kemudian mengevaluasi dari setiap poin-poin penting dari keseluruhan proses pembelajaran.

Komponen selanjutnya yang tidak bisa dipisahkan dari proses PBL adalah peran guru. Peran guru dan pendidik selain juga sebagai fasilitator memiliki tugas penting dalam mendorong siswa untuk lebih mandiri dalam kehidupan, dan mampu untuk belajar sepanjang hayat ${ }^{25}$. Guru yang berperan aktif dalam PBL adalah guru yang terus berpikir tentang beberapa hal yaitu 1) Bagaimana strategi untuk merancang dan menerapkan permasalahan yang ada di dunia nyata ke dalam proses pembelajaran, 2) bagaimana cara untuk menjadi fasilitator dan pembimbing bagi siswa dalam proses pemecahan masalah dan pengarahan diri untuk mengkontruksi pemikiran kognitif siswa, dan 3) bagaimana caranya agar siswa dapat memandang diri sendiri sebaga siswa yang aktif dalam proses pemecahan masalah yang disajikan.

${ }^{25}$ Rusman, Model-Model Pembelajaran: Mengembangkan Profesionalisme Guru. Hlm 234 
Selain dari pada di atas, guru juga memusatkan perhatiannya untuk menyiapkan perangkat berpikir siswa, menekankan belajar pendekatan kooperatif, memfasilitasi pembelajaran kelompok kecil dalam PBL, dan melaksanakan PBL secara keseluruhan proses yang telah tersusun secara sistematik.

jika didasarkan kepada klasifikasi model pengajaran Menurut Joice dkk (2009), Model Problem Based Learning termasuk dalam model pengajaran sosial, yaitu kelompok model pengajaran yang lebih menekankan dalam mengembangkan sesuatu yang dapat dilakukan secara bersama-sama serta menciptakan suasana demokratis dalam suatu kelas. Juga menekankan bagaimana interaksi sosial dapat meningkatkan hasil dalam suatu pembelajaran akademik.

Joice sendiri mengklasifikasikan model pembelajaran menjadi empat kelompok 1) Kelompok model yang mana dalam memproses suatu pengetahuan selalu menitikberatkan pada bagaimana peserta didik dapat memperoleh, mengelola, dan menjelaskan informasi dengan baik. Juga bagaimana dapat membantu peserta didik untuk menjadi pembelajar yang lebih baik, 2) Kelompok model pengajaran social, 3) Kelompok model pengajaran personal, yaitu model pengajaran yang memiliki tujuan untuk merancang sebuah sistem pendidikan yang mengadopsi non-directive philosophy sebagai inti dari pendekatan dalam pengajaran, 4) Kelompok model sistem-sistem perilaku, yaitu model pengajaran yang menekankan pada bagaimana menciptakan peserta didik yang bertingkah laku secara lebih produktif. ${ }^{26}$

\section{Tinjauan Pembelajaran Nahwu Berbasis PBL}

Secara bahasa, pembelajaran memiliki kata dasar belajar yang mendapat awalan pe dan akhiran -an yang berarti proses, cara atau perbuatan menjadikan manusia atau makhluk hidup belajar. ${ }^{27}$ Menurut Degeng menyatakan sebagaimana yang dikutip oleh Hamzah B. Uno, bahwa pembelajaran merupakan suatu upaya untuk membelajarkan siswa. ${ }^{28}$ Dalam pengertian tersebut mengandung arti bahwa dalam proses pembelajaran terdapat kegaiatan memilih, menetapkan, dan mengembangkan berbagai metode dan strategi untuk mencapai tujuan dari suatu pembelajaran.

${ }^{26}$ E. Joice, B., Weil, M. \& Calhoun, Models of Teaching: Model-Model Pengajaran, Terjemahan oleh Fawaid, A. \& Mirza A.,(Yogyakarta: Pustaka Pelajar, 2011).

${ }^{27}$ Kamus Besar Bahasa Indonesia. Hlm 17

${ }^{28}$ Uno, Perencanaan Pembelajaran. 
Untuk itu, seorang guru harus mampu secara kreatif memilihi model, metode dan strategi apa yang akan digunakan dalam suatu pembelajaran. Hal ini supaya tujuan pembelajaran dapat tercapai, baik dalam 1) Ranah Kognitif yaitu yang terkait dengan hasil belajar intelektual yang meliputi enam aspek, yaitu aspek pengetahuan, pemahaman, aplikasi, analisis, sintesis, serta evaluasi 2) Ranah afektif yang berkaitan dengan sikap. Ada lima aspek dalam ranah afektif yaitu meliputi aspek penerimaan, jawaban, penilaian, organisasi, dan internalisasi, dan 3) Ranah psikomotorik yaitu yang berkaitan dengan hasil belajar yang berupa keterampilan dan kemampuan untuk bertindak, ada enam aspek, yaitu gerakan refleks, keterampilan gerak dasar, kemampuan perceptual, ketepatan, keterampilan kompleks, dan gerakan ekspresif dan interpretatif. ${ }^{29}$

Kaitannya dengan Ilmu Nahwu, pembelajaran juga harus dilakukan dengan menggunakan model pembelajaran yang kreatif supaya tujuan pembelajaran Nahwu dapat tercapai. Hal Ini karena ilmu Nahwu merupakan integral dari pilarpilar ilmu bahasa Arab, yang terdiri dari empat cabang ilmu yaitu: ilmu bahasa (linguistik), ilmu Nahwu, ilmu Bayan, dan ilmu Sastra. ${ }^{30}$ Sehingga memiliki peran penting dalam ilmu bahasa arab.

Ilmu Nahwu sendiri Secara bahasa merupakan الطريق و الجهة (jalan dan arah). ${ }^{31}$ Sedangkan menurut ar-Razi, ilmu Nahwu adalah الطريق و القصد (jalan dan tujuan). ${ }^{32}$ Adapun secara istilah, Nahwu adalah ilmu untuk mengetahui akhir suatu kata baik secara i'rab atau bina. Ilmu Nahwu berisikan kaidah-kaidah tentang bagaimana seharusnya keadaan akhir suatu kata setelah tersusun dalam suatu kalimat. Definisi lain juga mengungkapkan bahwa ilmu Nahwu merupakan ilmu yang membahas kata-kata dalam bahasa Arab dari i'rab dan bina'.33 Hal ini juga senada dengan definisi menurut ulama klasik, bahwa ilmu Nahwu hanya terbatas pada permasalahan i'rab dan bina' (kondisi akhir sebuah kata sesuai dengan kedudukannya dalam kalimat) Mereka mendefinisikan ilmu Nahwu sebagai kaidah

${ }^{29}$ Sudjana, Penilaian Hasil Proses Belajar Mengajar.

${ }^{30}$ Ibnu Khaldun, Al Muqoddimah (Maktabah Syamilah).

31 al-Shaykh Majd al-Din Muhammad bin Ya'qûb Al-Fayrûz Abâdî, Qâmûs Al-Muhît (Beirut: Dârl al-Fikr, 1983).

32 al-Imâm Muhammad bin Abî Al-Qadîr Bakr 'Abd Al-Râzî, Mukhtâr AlShahhah (Beirut: Dârl al-Kutub al-'Ilmiyah, 1992).

${ }^{3}$ Sari, "Analisis Kesulitan Pembelajaran Nahwu Pada Siswa Kelas Viii Mts Al Irsyad Gajah Demak Tahun Ajaran 2015/2016." 
atau aturan untuk mengenal hal ihwal kata-kata bahasa Arab, baik dari segi i'rab maupun bina'. ${ }^{34}$

Namun, seiring dengan berkembangnya penelitian dan pengkajian tentang analisis kebahasaan, para pakar bahasa kemudian cenderung mengubah dan memperluas pengertian dan kajian ilmu Nahwu, menjadi tidak hanya terfokus pada pembahasan tentang i'rab dan bina' bagi sebuah kata saja, tetapi juga mencakup pembahasan tentang penjaringan kosakata, pertalian interen antara beberapa kata, penyatuan beberapa kata dalam suatu rentetan bunyi tertentu dan hubungan antara beberapa kata yang ada dalam kalimat serta komponenkomponen yang membentuk sebuah prasa. ${ }^{35}$

Ilmu Nahwu memiliki berbagai materi yang kompleks bagi banyak siswa sehingga dapat menimbulkan berbagai permasalahan dalam penerapannya. Hal ini seperti apa yang ditemukan dalam penelitian yang dilakukan oleh Muallif, ia menemukan bahwa terdapat sekelompok orang yang cenderung untuk meninggalkan kaidah-kaidah tentang i'rab karena merasa cukup dengan mensukûn akhir setiap kata. Dan kecenderungan yang seperti itu merupakan kecenderungan yang tidak dapat diterima. ${ }^{36}$

Model pembelajaran berbasis masalah atau Problem Based Learning hadir untuk membantu mengatasi hambatan-hambatan siswa dalam mempelajari ilmu Nahwu selama ini. Materi ilmu Nahwu yang terkesan rumit dan berbelit-belit serta motivasi yang rendah dari siswa adalah di antara pengaruh hambatan pembelajaran ilmu Nahwu. Problem Based Learning sebagai model pembelajaran diharapkan mampu mengurai kesulitan siswa dalam pembelajaran ilmu Nahwu. Hal ini karena dalam Problem Based Learning siswa dituntut untuk aktif serta kolaboratif dan mengkontruksi sendiri pemikiran dan analisisnya serta memberikan kebiasaan pada siswa untuk mampu berpikir kritis dan solutif dalam menyelesaikan berbagai permasalahan dalam materi ilmu Nahwu. Sehingga siswa akan mengalami sendiri pembelajaran yang bermakna dan pada akhirnya dapat memudahkan siswa dalam mempelajari ilmu Nahwu.

${ }^{34}$ A. Mualif, "Metodologi Pembelajaran Ilmu Nahwu Dalam Pendidikan Bahasa Arab," Jurnal AL-HIKMAH 1, no. 1 (2019): 26-36.

35 Tâha Husain, Mushkilat Al-I'râb, Majallah Majma' Al-Lughah Al- 'Arabiyyah (Cairo: alHay'ah al Âmmah li Shu'ûn al-Matabi' al Amîriyah, 1959).

36 Mualif, "Metodologi Pembelajaran Ilmu Nahwu Dalam Pendidikan Bahasa Arab." 


\section{Deskripsi Proses Pelaksanaan Eksperimen}

Sebelum melakukan proses eksperimen, peneliti telah melakukan pretest terlebih dahulu. Pretest dilakukan terhadap dua kelas sampel yang telah ditentukan, yaitu kelas eksperimen dan kelas control. Pretest dilakukan dengan menggunakan soal yang telah divalidasi oleh ahli dan telah di uji validitas dengan bantuan software SPSS 20. Hal ini dilakukan untuk mengetahui bahwasanya keadaan dua kelas tersebut dalam keadaan sama.

Proses pelaksanaan pembelajaran Nahwu di kelas eksperimen dilakukan sebanyak 3 kali dengan menggunkan model pembelajaran Problem Based Learning $(P B L)$. Adapun gambaran setiap pelaksanaan pembelajarannya adalah sebagai berikut: 1) Pendidik memulai pembelajaran dengan membaca doa dan memberikan motivasi kepada peserta didik. 2) Pendidik menyampaikan tujuan pembelajaran yang akan dicapai kepada peserta didik, 3) Pendidik membagi peserta didik ke dalam beberapa kelompok, masing-masing beranggotakan 4-5 peserta didik, 4) Pendidik memberikan suatu permasalahan Nahwu kepada masing-masing kelompok yaitu berupa teks berbahasa arab dan siswa diminta untuk memahami dan membaca teks denga benar. 5) Peserta didik melaksanakan proses pembelajaran Problem Based Learning yang dimulai dengan berdiskusi dengan anggota kelompok untuk menyelesaikan permasalahan Nahwu yang telah diberikan oleh pendidik dengan menggunakan berbagai sumber pembelajaran. 6) setiap kelompok memaparkan hasil diskusi mereka kepada kelompok yang lain dan kelompok lain memberikan masukan dan sanggahan serta pertanyaan, 7) Pendidik melakukan evaluasi terhadap hasil diskudi masing-masing kelompok, 8) Pendidik dan peserta didik menyimpulkan materi yang telah dipelajari, dan terakhir, pendidik menutup proses pembelajaran dengan salam.

Tabel.1. Pelaksanaan pembelajaran di Kelas Eksperimen

\begin{tabular}{|c|l|l|l|}
\hline $\begin{array}{l}\text { Pertemuan } \\
\text { ke- }\end{array}$ & Hari/tanggal & $\begin{array}{l}\text { Alokasi } \\
\text { waktu }\end{array}$ & Materi \\
\hline 1 & $\begin{array}{l}\text { Selasa, 14 } \\
\text { Januari 2020 }\end{array}$ & 1 JP & $\begin{array}{l}\text { Membahas tentang } \\
\text { kalimah dan jumlah }\end{array}$ \\
2 & $\begin{array}{l}\text { Selasa, 21 } \\
\text { Januari 2020 }\end{array}$ & 2 JP & Membahas tentang i'rob \\
& & & \\
\end{tabular}




3 Selasa, $28 \quad 1 \mathrm{JP} \quad$ Membahas tentang tarkib

Januari 2020 Idhofah dan Na'at Man'ut

Sedangkan proses pelaksanaan pembelajaran di kelas kontrol juga dilaksanakan sebanyak 3 kali dengan menggunakan model ceramah atau konvensional (tidak menggunakan model pembelajaran Problem Based Learning). Adapun gambaran proses pembelajaran di kelas kontrol adalah sebagai berikut: 1) Pendidik memulai kegiatan pembelajaran dengan membaca doa dan memberikan sedikit motivasi kepada peserta didik, 2) Pendidik menyampaikan tujuan pembelajaran yang akan dicapai selama proses pembelajaran berlangsung, 3) Pendidik menampilkan materi yang yang akan disampaikan. 4) Peserta didik mengajukan pertanyaan tentang materi yang kurang dipahami kepada pendidik, 5) Pendidik memberikan pertanyaan tentang materi yang telah disampaikan kepada peserta didik, 6) Pendidik dan peserta didik menyimpulkan hasil pembelajaran dan terakhir pendidik menutup proses pembelajaran dengan salam.

Tabel. 2 Pelaksanaan Pembelajaran di Kelas Kontrol

\begin{tabular}{|c|c|c|c|c|}
\hline Pertemuan & Hari/tanggal & & $\begin{array}{l}\text { Alokasi } \\
\text { waktu }\end{array}$ & Materi \\
\hline 1 & $\begin{array}{l}\text { Sabtu, } \\
\text { Januari } 2020\end{array}$ & 11 & $1 \mathrm{JP}$ & $\begin{array}{l}\text { Membahas tentang } \\
\text { kalimah dan jumlah }\end{array}$ \\
\hline 2 & $\begin{array}{l}\text { Sabtu, } \\
\text { Januari } 2020\end{array}$ & 18 & $2 \mathrm{JP}$ & $\begin{array}{l}\text { Membahas } \\
\text { i'rob }\end{array}$ \\
\hline 3 & $\begin{array}{l}\text { Selasa, } \\
\text { Januari } 2020\end{array}$ & 25 & $1 \mathrm{JP}$ & $\begin{array}{l}\text { Membahas tentang } \\
\text { tarkib Idhofah dan } \\
\text { Na'at Man'ut }\end{array}$ \\
\hline
\end{tabular}

\section{Gambaran Umum Instrumen Penelitian}

Butir-butir soal pretest dan posttest yang digunakan sebagai instrumen penelitian ini meliputi soal yang telah disesuaikan dengan tujuan dan indikator penguasaan ilmu Nahwu secara umum, yaitu 1) siswa dapat membedakan antara struktur, ungkapan, kata dan kalimat dalam bahasa Arab, 2) siswa dapat membedakan antara kalimat yang salah dan benar, 3) siswa mampu memahami apa yang didengar dan dibaca, dan 4) siswa mampu menggunakan bahasa Arab secara tulisan maupun lisan secara baik dan benar. 
Indikator tersebut berdasarkan pada pandangan Rusydi Ahmad Thuaimah yang menjelaskan bahwa tujuan pembelajaran Nahwu secara fungsional adalah sebagai berikut, pertama: Untuk membekali peserta didik dengan kaidah-kaidah kebahasaan yang dapat menjaganya dari kesalahan-kesalahan berbahasa; kedua: untuk mengingkatkan kemampuan intelektual yang dapat membuat mereka untuk berpikir logis sehingga mereka dapat membedakan antara struktur (tarakib), ungkapan ('ibarat), kata, dan kalimat; ketiga: untuk membiasakan peserta didik agar cermat dalam mengamati contoh-contoh, melakukan perbandingan, analogi, dan penyimpulan serta mememberikan kemampuan kepada peserta didik untuk mampu memiliki kepekaan bahasa dan sastra (dzauq lughawi). Karena kajian Nahwu didasarkan pada analisis lafadz, ungkapan, gaya bahasa, serta mampu membedakan antara kalimat yang salah dan yang benar; keempat: untuk melatih peserta didik agar mampu menirukan dan mencontoh kalimat, uslub (gaya bahasa), ungkapan, dan performa kebahasaan (al-ada' al-lughawi) secara tepat, serta agar mereka mampu menilai aspek kebahasaan (lisan maupun tulisan) yang salah menurut kaidah yang baik dan benar; kelima: untuk meningkatkan kemampuan peserta didik dalam memahami apa yang mereka dengar dan yang tertulis; keenam: untuk memberikan kemampuan kepada peserta didik dalam membaca, berbicara, dan menulis atau mampu menggunakan bahasa Arab lisan dan tulisan secara baik dan benar. ${ }^{37}$

\section{Hasil Uji Instrumen}

Standar instrumen penelitian yang baik adalah yang memenuhi dua persyaratan penting yaitu valid dan reliable. ${ }^{38}$ Dalam peneletian ini, peneliti menggunakan instrument berupa soal pretest dan posttest. Soal pretest dan posttest berjumlah 40 butir soal pilihan ganda. Namun sebelumnya soal tersebut diujikan dahulu kepada siswa dengan uji validitas. Dalam uji validasi isi, peneliti menggunakan bantuan software SPSS 20 serta divalidasikan oleh ahli, yaitu guru pembimbing penelitian dan dosen pembimbing.

Dalam uji validitas instrument menggunakan software SPSS 20, diperoleh soal valid Sebanyak 33 butir soal dari jumlah total 40 butir soal. Sedangkan hasil

37 Rusydi Ahmad thu'aimah dan Muhammad al-Sayyid Manna', Tadris Al-Arabiyyah Fi AlTa'lim Al-'Am; Nazhariyyah Wa Tajrib (Kairo: Dar al-Fikr al-Araby, 2000) hlm. 54-55.

${ }^{38}$ Suharsimi Arikunto, Prosedur Penelitian Suatu Pendekatan Paktik (Jakarta: Rineka Cipta, 2013). Hlm. 158. 
dari uji reliabilitas 33 butir soal pilihan ganda tersebut diperoleh hasil reliabilitas sebesar 0.949 dan termasuk dalam kategori reliabilitas baik.

\section{Deskripsi Hasil Statistik Pretest dan Posttest pada Kelas Eksperimen dan Kelas Kontrol}

Setelah peneliti melakukan proses eksperimen, maka diperoleh hasil dari pretest kelas eksperimen yaitu memiliki rata-rata pretest sebesar 74 , dengan nilai tertingginya yaitu 100 dan nilai terendahnya sebesar 61 dari 30 peserta didik. Sedangkan hasil pretest dari kelas kontrol memilik rata-rata sebesar 72, dengan nilai tertinggi sebesar 94 dan nilai terendahnya sebesar 45 dari 30 peserta didik. Artinya beda rata-rata nilai pretest antara kelas ekesperimen dan kelas kontrol yaitu sebesar 2 point,

Setelah peneliti memberikan perlakuan sebanyak 3 kali pertemuan, kemudian peneliti melakukan posttest. Dari hasil posttest tersebut diperoleh hasil rata-rata dari kelas eksperimen sebesar 85, dengan nilai tertinggi sebesar 100 dan nilai terendahnya sebesar 61. Adapun hasil posttest dari kelas kontrol diperoleh rata-rata sebesar 74, sedangkan nilai tertinggi sebesar 88 dan nilai terendahnya 48. Artinya, beda rata-rata nilai posttest dari kelas eksperimen dan kelas kontrol sebesar 11 point.

\section{Analisis Data}

1) Uji Normalitas

Uji normalitas data dilakukan dengan menggunakan software SPSS 20. Adapun dasar pengambilan keputusannya yaitu apabila nilai signifikansi lebih besar dari 0,05 maka data yang digunakan berdistribusi normal. Namun, apabila nilai signifikansi lebih kecil dari 0,05 maka data yang digunakan tidak berdistribusi normal.

Tabel. 3 Hasil uji normalitas data pretest dan posttest dengan menggunakan SPSS 20.

\begin{tabular}{|ll|r|}
\hline \multicolumn{2}{|c|}{ Data } & .Sig \\
\hline & Pretest Eks (PBL) & .172 \\
Hasil belajar & Posttest eks (PBL) & $.200^{*}$ \\
siswa & Pretest Kontrol & .157 \\
& Posttest Kontrol & $.200^{*}$ \\
\hline
\end{tabular}

Dari data di atas dapat diketahui bahwa nilai signifikansi dari hasil pretest kelas eksperimen yaitu sebesar 0,172, Maka data yang digunakan berarti berdistribusi normal. Sedangkan nilai signifikansi dari hasil pretest kelas kontrol 
sebesar 0,157 yaitu lebih besar dari 0,05, artinya data yang digunakan berdistribusi normal. Sehingga dapat disimpulkan bahwa baik kelas eksperimen maupun kelas kontrol berawal dari kemampuan yang sama. Hal ini karena data pretest kelas eksperimen dan kelas kontrol berdistribusi normal.

Setelah melakukan beberapa kali pertemuan untuk memberikan treatment, maka diperoleh data posttest kelas eksperimen dengan signifikansi sebesar 0,200 lebih besar dari 0,05 yang artinya data berdisrtribusi normal. Sedangkan nilai signifikansi dari data posttest kelas kontrol juga sebesar 0,200 yang berarti data juga berdistribusi normal.

Setelah uji normalitas data pretest dan posttest, langkah selanjutnya yag dilakukan peneliti yaitu menguji normalitas nilai gain. Adapun hasilnya adalah sebagai berikut.

Tabel. 4 Hasil Uji Normalitas Gain

\begin{tabular}{|l|l|r|r|r|}
\hline \multirow{2}{*}{} & Kelas & \multicolumn{3}{|c|}{ Kolmogorov-Smirnov $^{\mathrm{a}}$} \\
\cline { 3 - 5 } & & \multicolumn{1}{c|}{ Statistic } & \multicolumn{1}{c|}{ Df } & \multicolumn{1}{c|}{ Sig. } \\
\hline \multirow{2}{*}{ Gain } & Kelas Eksperimen & .154 & 30 & .069 \\
& Kelas Kontrol & .116 & 30 & $.200^{*}$ \\
\hline
\end{tabular}

Dari tabel tersebut didapatkan nilai signifikansi gain untuk kelas eksperimen adalah sebesar 0,069 lebih besar dari 0,050 yang berarti data berdistribusi normal. Sedangkan nilai signifikansi gain untuk kelas kontrol adalah 0,200 lebih besar dari 0,050. Artinya kedua data gain baik dari kelas eksperimen maupun kelas kontrol berdistribusi normal. Sehingga semua data dapat digunakan untuk uji selanjutnya.

2) Uji Homogenitas

Peneliti melakukan Uji homogenitas untuk mengetahui apakah kelas eksperimen dan kelas kontrol memiliki variasi yang homogen atau tidak. Peneliti menggunakan bantuan software SPSS 20 dengan uji ANNOVA untuk mengujinya.

Ketentuan uji homogenitas yaitu apabila nilai signifikansi kurang dari 0,050 maka data dianggap tidak homogen. Sebaliknya, jika nilai signifikansi lebih dari 0,050 maka data yang digunakan bersifat homogen. Untuk hasil uji homogenitas dari data pretest dan posttest baik untuk kelas eksperimen dan kelas kontrol adalah sebagai berikut:

Tabel. 5 Hasil uji homogenitas data pretest dan posttest dengan menggunakan SPSS 20. 


\begin{tabular}{|l|l|l|l|}
\hline No & Data & Sig & Keterangan \\
\hline 1 & Pretest (Eks+Kontrol) & 0.000 & Tidak Homogen \\
\hline 2 & Posttest (Eks+Kontrol) & 0.879 & Homogen \\
\hline
\end{tabular}

Dari data tersebut dapat disimpulkan bahwa data pretest antara kelas eksperimen dan kelas kontrol tidak bersifat homogen karena nilai signifikansinya 0,000 yakni kurang dari 0,050. Sedagkan hasil nilai posttest kelas eksperimen dan kontrol bersifat homogen karena nilai signifikansinya sebesar 0,879 yang berarti lebih dari 0,05.

Langkah selanjutnya peneliti melakukan uji homogenitas terhadap nilai gain dan menunjukkan hasil sebagai berikut:

Tabel.6 Uji Homogenitas nilai gain

Test of Homogeneity of Variances

Gain
\begin{tabular}{|r|r|r|r|}
\hline Levene Statistic & df1 & \multicolumn{1}{|c|}{ df2 } & \multicolumn{1}{c|}{ Sig. } \\
\hline 14.489 & 1 & 58 & .000 \\
\hline
\end{tabular}

Dari tabel tersebut didapati bahwa nilai signifikansi nilai gain sebesar 0,000 yang artinya lebih kecil dari 0,05. berarti nilai gain tersebut tidak bersifat homogen. Namun uji homogen ini tidak menjadi syarat mutlak untuk kemudian dilakukan Uji T. sehingga peneliti kemudian melakukan uji T untuk semua data.

3) Uji Hipotesis

Uji Hipotesis dilakukan untuk membuktikan asumsi dasar peneliti dari hasil sebuah pengujian. Namun, sebelum peneliti melakukan uji hipotesis, syarat mutlak yang harus terpenuhi adalah data harus berdistribusi normal. Dan karena data yang diperoleh sudah berdistribusi normal, maka langkah selanjutnya yaitu peneliti melakukan uji hipotesis dengan bantuan software SPSS 20 dengan uji independent sample T test. Adapun rumusan hipotesisnya adalah sebagai berikut: $\mathrm{H}_{\mathrm{o}}=$ apabila signifikansi/probabilitas lebih dari 0,050 maka model pembelajaran problem based learning tidak berpengaruh dalam meningkatkan hasil belajar Nahwu siswa. 
$\mathrm{H}_{1}=$ apabila nilai signifikansi/probabilitas kurang dari 0,050 maka model pembelajaran problem based learning dianggap berpengaruh dalam meningkatkan hasil belajar Nahwu siswa.

Adapun hasil perhitungan dengan menggunakan software SPSS 20 adalah sebagai berikut:

Tabel. 7 Hasil Uji T nilai pretest dan posttest

\begin{tabular}{|l|l|r|r|r|r|r|}
\hline \multicolumn{2}{|c|}{} & \multicolumn{2}{|c|}{$\begin{array}{l}\text { Levene's Test for } \\
\text { Equality of } \\
\text { Variances }\end{array}$} & \multicolumn{2}{c|}{ t-test for Equality of Means } \\
\cline { 3 - 7 } \multicolumn{2}{|c|}{} & F & Sig. & T & df & Sig. (2-tailed) \\
\hline $\begin{array}{l}\text { Hasil } \\
\text { Pretest }\end{array}$ & $\begin{array}{l}\text { Equal variances } \\
\text { assumed }\end{array}$ & 18.078 & .000 & .769 & 58 & .445 \\
\cline { 2 - 7 } & $\begin{array}{l}\text { Equal variances not } \\
\text { assumed }\end{array}$ & & & .769 & $\begin{array}{r}44.96 \\
2\end{array}$ \\
\hline $\begin{array}{l}\text { Hasil } \\
\text { Posttes } \\
\mathrm{t}\end{array}$ & $\begin{array}{l}\text { Equal variances } \\
\text { assumed }\end{array}$ & .023 & .879 & 4.108 & 58 & .000 \\
\hline & $\begin{array}{l}\text { Equal variances not } \\
\text { assumed }\end{array}$ & & & 4.108 & 57.96 \\
\\
\hline
\end{tabular}

Dari tabel tersebut dapat disimpulkan bahwa nilai signifikansi dari uji $\mathrm{T}$ nilai pretest diperoleh hasil sebesar 0,445 yaitu lebih besar dari 0,05 , yang berarti antara kelas eksperimen dan kelas kontrol tidak ada perbedaan yang signifikan. Ini memiliki arti bahwa sebelum diberikan perlakuan, kedua kelas tersebut dalam keadaan yang sama kemampuannya.

Adapun hasil uji T dari nilai posttest diperoleh nilai signifikansi sebesar 0,000 lebih kecil dari 0,05o maka dapat disimpulkan bahwa terdapat perbedaan rata-rata hasil belajar Nahwu siswa di kelas eksperimen yang menggunakan model pembelajaran Problem Based Learning dan di kelas kontrol yang tidak menggunakan model PBL (menggunakan model konvensional) dalam pembelajaran.

Selanjutnya, peneliti melakukan uji paired sample $T$ test dengan bantuan software SPSS 20 yang bertujuan untuk mengetahui apakah terdapat perbedaan rata-rata antara kedua kelompok yang berhubungan tersebut. Dan hasilnya adalah sebagai berikut:

Tabel. 8 Hasil uji paired sample T test pretest-postest kelas eksperimen dan kelas kontrol 


\begin{tabular}{|l|r|r|}
\hline \multicolumn{1}{|c|}{ Data } & Sig (2-Tailed) & Keterangan \\
\hline Pretest Eks - Posttest Eks & .000 & Terdapat Perbedaan \\
\hline $\begin{array}{l}\text { Pretest Kontrol - Posttest } \\
\text { Kontrol }\end{array}$ & .629 & Tidak Terdapat perbedaan \\
\hline
\end{tabular}

Tabel di atas menunjukkan bahwa pair 1 yang merupakan data kelas eksperimen memiliki nilai signifikansi 0,000 lebih kecil dari 0,05 yang artinya model pembelajaran $P B L$ memiliki pengaruh terhadap hasil belajar Nahwu. Adapun data pair 2 yang merupakan kelas kontrol memiliki angka 0,629 lebih besar dari 0,05 yang memiliki arti bahwa model pembelajaran konvensional tidak berpengaruh dalam meningkatkan hasil belajar Nahwu.

Dari hasil uji Paired sample T test di atas dapat disimpulkan bahwa model pembelajaran problem based learning (PBL) lebih berpengaruh terhadap hasil belajar Nahwu siswa kelas X SMA Sains Wahid Hasyim secara signfikan dibandingkan dengan yang menggunakan model konvensional (kelas kontrol).

\section{Penerapan Model Pembelajaran Problem Based Learning (PBL) dalam pembelajaran Nahwu}

Peneliti menerapkan model pembelajaran Problem Based Learning dalam pembelajaran Nahwu dimulai dari menentukan masalah terlebih dahulu. Penentuan masalah dalam materi Nahwu berangkat dari pengalaman guru selama mengajar siswa kelas eksperimen. Menurut guru mata pelajaran Nahwu, terdapat beberapa materi Nahwu yang dianggap problematik bagi siswa kelas X. Di antaranya adalah materi tentang idhofah dan na'at man'ut. Pada kedua materi tersebut, siswa seringkali kurang mampu untuk membedakan antara mana yang kalimah yang berupa susunan idhofah dan mana yang berupa susunan na'at man'ut. Sebagai contoh antara kalimat طالبُ عالمٍ dan. Pada kalimat tersebut, kalimat yang pertama adalah susunan na'at man'ut, sedangkan kalimat yang kedua adalah susunan idhofah. Namun seperti kasus di atas, siswa kelas X seringkali bingung dalam membedakannya. Untuk itu, oleh peneliti hal ini dianggap sebagai problem yang bisa menjadi pijakan masalah dalam penerapan model pembelajaran Problem Based Learning dalam materi Nahwu.

Hal selanjutnya yang dilakukan peneliti adalah membagi siswa ke dalam beberapa kelompok, yang mana setiap kelompoknya terdiri dari 4-5 siswa, kemudian peneliti memberikan waktu kepada siswa untuk menganalisis masalah 
tersebut melalui teks arab yang terdapat kasus problematik materi Nahwu. Yaitu siswa diminta untuk membaca dan memahami maksud dari teks berbahasa Arab tersebut. Hal ini dilakukan dengan bantuan peneliti sebagai fasilitator dan berbagai sumber belajar yang sudah ada. Setelah analisis kolaboratif selesai dilakukan oleh kelompok, selanjutnya yaitu siswa memaparkan hasil analisis masalah yang dilakukan oleh siswa. Selanjutnya peneliti mereview serta memberikan solusi atas masalah yang dirasa belum terpecahkan secara menyeluruh mengenai materi Nahwu. Dan terakhir, peneliti memberikan kesimpulan atas apa yang telah dipelajari. Langkah-langkah yang dilakukan tersebut sesuai dengan langkah-langkah pembelajaran problem based learning secara umum.

Penerapan model pembelajaran Problem Based Learning (PBL) dalam pembelajaran Nahwu disambut positif oleh siswa kelas eksperimen. Karena dengan model pembelajaran PBL, siswa memiliki peran aktif dalam pembelajaran. Selain itu, siswa-siswa yang sebelumnya merasa tertinggal dalam memahami materi Nahwu menjadi lebih mampu memahami karena tanggung jawab yang dimiliki oleh setiap anggota kelompok harus mampu memahami dan memaparka hasil analisis pemecahan masalahnya.

\section{Kesimpulan}

Pelaksanaan model pembelajaran problem based learning pada pembelajaran Nahwu di SMA Sains Wahid Hasyim kelas X diawali dengan proses orientasi pada materi-materi yang hendak dipelajari lebih dulu, selanjutnya guru membagi peserta didik ke dalam beberapa kelompok, setiap kelompok terdiri dari 4-5 anak. Setelah itu, guru membagikan suatu kasus permasalahan materi Nahwu yang problematik kepada setiap kelompok yaitu dengan memberikan suatu teks berbahasa Arab. kemudian peserta didik diminta untuk mendiskusikan tentang masalah sesuai dengan materi yang ditentukan serta merumuskan pemecahan masalahnya. Setelah pemasalahan terpecahkan, peserta didik dari setiap kelompok menjelaskan hasil dari pemecahan masalah berupa bacaan berbahasa arab dihadapan peserta didik lainnya. Langkah terakhir guru memberikan review dan penilaian terhadap hasil penyelesaian masalah yang dilakukan oleh setiap 
kelompok dan memberikan kesimpulan dari hasil pembelajaran yang telah dilaksanakan.

Apabila dilihat dari nilai pretest dan posttest yang telah dilakukan peneliti, terdapat pengaruh pada penggunaan model pembelajaran problem based learning terhadap hasil belajar siswa pada mata pelajaran Nahwu. Hal ini berdasarkan hasil uji T nilai posttest yang mana diperoleh nilai signifikansi sebesar 0,000 lebih kecil dari 0.05 yang artinya ada perbedaan yang signifikan antara nilai posttes kelompok eksperimen dan kelompok control setelah diberikan perlakuan yang berbeda. Dengan kata lain model pembelajaran Problem Based Learning (PBL) memiliki pengaruh terhadap peningkatan hasil belajar Nahwu.

\section{REFERENSI}

Acep Hermawan. Metodologi Pembelajaran Bahasa Arab. Jakarta: PT. Rosda Karya, 2011.

Al-Fayrûz Abâdî, al-Shaykh Majd al-Din Muhammad bin Ya'qûb. Qâmûs Al-Muhît. Beirut: Dârl al-Fikr, 1983.

Al-Râzî, al-Imâm Muhammad bin Abî Al-Qadîr Bakr 'Abd. Mukhtâr AlShahhah. Beirut: Dârl al-Kutub al-'Ilmiyah, 1992.

Amir, M. Taufiq. Inovasi Pendidikan Melalui Problem Based Learning, Bagaimana Pendidik Memberdayakan Pemelajar Di Era Pengetahuan. Jakarta: Kencana, 2009.

Arends. Learning to Teach. 6th ed. New York: McGrawHill, 2008.

Arikunto, Suharsimi. Prosedur Penelitian Suatu Pendekatan Paktik. Jakarta: Rineka Cipta, 2013.

Dalyono. Psikologi Pendidikan. Jakarta: Rineka Cipta, n.d.

Fahmi, Ali Akrom. Ilmu Nahwu Dan Sharaf 2 (Tata Bahasa) Praktis Dan Aplikatif. Jakarta: Raja Grafindo Persada, 1995.

Husain, Tâha. Mushkilat Al-I'râb, Majallah Majma' Al-Lughah Al- 'Arabiyyah. Cairo: al-Hay'ah al Âmmah li Shu'ûn al-Matabi' al Amîriyah, 1959.

Indonesia, Pemerintah Republik. Undang-Undang Sistem Pendidikan Nasional No. 20 Tahun 2003. Jakarta, Indonesia: Sinar Grafinda, 2009.

Istiningsih, Galih, Ela Minchah L.A, and Evik Prihalina. "Pengembangan Model Pembelajaran 'Promister' Untuk Meningkatkan Hasil Belajar Wayang 
Pandhawa Pada Siswa Sekolah Dasar.” Jurnal Holistika II, no. 2 (2018): 94103.

https://jurnal.umj.ac.id/index.php/holistika/article/download/2637/2788.

Joice, B., Weil, M. \& Calhoun, E. Models of Teaching: Model-Model Pengajaran. Yogyakarta: Pustaka Pelajar, 2009.

Khaldun, Ibnu. Al Muqoddimah. Maktabah Syamilah, n.d.

Ma'rifatun. "Strategi Pembelajaran Nahwu Saraf Di MA Pondok Pesantren." Jurnal Al-Ghazali 2, no. 2 (2019): 103-116. https://ejournal.stainupwr.ac.id/.

Machalli, Imam. Metode Penelitian Kuantitatif. Yogyakarta: Pustaka an-Nur liq anNur, 2017.

Manna', Rusydi Ahmad thu'aimah dan Muhammad al-Sayyid. Tadris Al-Arabiyyah Fi Al-Ta'lim Al-'Am; Nazhariyyah Wa Tajrib. Kairo: Dar al-Fikr al-Araby, 2000.

Mardliyyah, Aisyam. “Implementasi Metode Qiyasi Dalam Pembelajaran Nahwu Kelas XI MA Ibnu Qoyyim Putra Yogyakarta." at-Tarbawi 4, no. 2 (2019).

Mualif, A. "Metodologi Pembelajaran Ilmu Nahwu Dalam Pendidikan Bahasa Arab." Jurnal AL-HIKMAH 1, no. 1 (2019): 26-36.

Mujiono, Dimyati dan. Belajar Dan Pembelajaran. Jakarta: Rineka Cipta, 1999.

Muniroh, Alimul. Academic Engagement; Penerapan Model Problem Based Learning Di Madrasah. Yogyakarta: LKIS, 2015.

Nashoih, Afif Kholisun, and M. Faridl Darmawan. "Pengembangan Bahan Ajar Nahwu Berbasis Kontrastif Untuk Mengatasi Interferensi Bahasa Indonesia Terhadap Bahasa Arab." Arabiyatuna : Jurnal Bahasa Arab 3, no. 2 (2019): 335. Nelfiyanti, and Didi Sunardi. "PENERAPAN METODE PROBLEM BASED LEARNING DALAM PELAJARAN AL - ISLAM II DI FAKULTAS TEKNIK UNIVERSITAS MUHAMMADIYAH JAKARTA." Spektrum Industri 15, no. 1 (2017): 1-119.

Ningsih, Puji Rahayu, Arif Hidayat, and Sentot Kusairi. "Penerapan Problem Based Learning Untuk Meningkatkan Kemampuan Berpikir Kritis Dan Hasil Belajar Siswa Kelas III." Jurnal Pendidikan: Teori , Penelitian dan Pengembangan 3, no. 12 (2018): 1587-1593. http://journal.um.ac.id/index.php/jptpp/.

Nurliani, Nina, Herman Subarjah, and Atep Sujana. "Pengaruh Model Pembelajaran Berbasis Masalah Terhadap Hasil Belajar Peserta Didik Pada Materi Peristiwa Alam." Jurnal Pena Ilmiah 1, no. 1 (2016): 981-990.

Rusman. Model-Model Pembelajaran: Mengembangkan Profesionalisme Guru. 
Rajawali Pers/PT Raja Grafindo Persada, 2011.

Sahrah. "Pembelajaran Nahwu Di Madrasah Quran Wa Al Hadits (MQWH) Pondok Pesantren Al-Aziziyah Kapek Gunungsari Kabupaten LOMBOK Barat.” ElTsaqafah: Jurnal Jurusan PBA XVI, no. 2 (2017): 189-210. https://journal.uinmataram.ac.id/index.php/eltsaqafah/article/view/451.

Sardiman. Interaksi Dan Motivasi Belajar Mengajar. Jakarta: Raja Grafindo Persada, 2000.

Sari, Ana Wahyuning. "Analisis Kesulitan Pembelajaran Nahwu Pada Siswa Kelas

Viii Mts Al Irsyad Gajah Demak Tahun Ajaran 2015/2016." Lisanul' Arab: Journal of Arabic Learning and Teaching 6, no. 1 (2017): 16-17.

Savery, J.R. "Overview Of Problem-Based Learning: Devinition and Distinction Interdisciplinary." Journal Problem-based Learning 1, no. 1 (2006): 9-20. https://doi.org/10.7771/1541-5015.1002.

Sudjana, Nana. Penilaian Hasil Proses Belajar Mengajar. Bandung: Remaja Rosdakarya, 2010.

Syah, Muhibbin. Psikologi Pendidikan. Bandung: PT. Remaja Rosdakarya, 2000.

Tyas, R. "Kesulitan Penerapan Problem Based Learning Dalam Pembelajaran Matematika." Tecnoscienza 2, no. 1 (2017): 43-52.

Uno, Hamzah B. Perencanaan Pembelajaran. Jakarta: Bumi Aksara, 2012.

Winaputra, U. S. Mengajar Di Perguruan Tinggi: Model-Model Pembelajaran Inovatif. Jakarta: PAU-PPAI Universitas Terbuka, 2005.

Kamus Besar Bahasa Indonesia. Jakarta: Balai Pustaka, 2005. 